\title{
Performance Characteristics of a Gasohol Fueled S.I Engine.
}

\author{
Laminu S. Kuburi, David O. Obada, Ibraheem A. Samotu, Chike V. Chira \\ Obinna A. Osuchukwu and M. Jeremiah. \\ Department of Mechanical Engineering, Ahmadu Bello University, Zaria, Nigeria.
}

\begin{abstract}
Ethanol is a renewable fuel which has the added advantage of improving performance in typically knock-limited operating regions due to the higher octane rating of the fuel. Ethanol was synthesized from groundnut seeds using fermentation method. An experiment was then designed to run a gasoline engine. In this work, the effect of ethanol addition to gasoline on the performance characteristics of a spark ignition engine at various speeds was established. Gasoline was blended with $20-80 \%$ of the extracted ethanol in an interval of $20 \%$. Results of the engine test indicated that blending ethanol in a proportion of $40 \%$ with gasoline can be used as a supplementary fuel in modern spark ignition engines as it is expected to achieve optimum performance on the engine.
\end{abstract}

Keywords: - Ethanol, Gasoline, performance, Spark ignition engine.

\section{INTRODUCTION}

While ethanol is an attractive option for offsetting dependence on petroleum based gasoline, the differences in fuel properties between gasoline and ethanol can significantly alter engine performance [1], [2], [3]. Due to the different molecular structure of ethanol, the stoichiometric air-fuel ratio of ethanol is substantially different than gasoline and the air and fuel controllers must target different values for ethanol blends. Ethanol also has a different laminar flame speed than gasoline; therefore, the rate at which flames propagate during combustion will differ depending on the fuel ethanol content and combustion phasing will be directly affected. In addition, as a result of its higher octane rating, ethanol has a higher resistance to knock than gasoline. Ethanol fuel is ethanol (ethyl alcohol), the same type of alcohol found in alcoholic beverages. It can be used mainly as a biofuel alternative to gasoline, and is widely used by flex-fuel light vehicles in Brazil, and as oxygenate to gasoline in the United States. Together, both countries were responsible for $89 \%$ of the world's ethanol production in 2008 [4]. As noted by Blume [5], the following are the key reasons for which ethanol is attractive as a substitute to gasoline: Ethanol is $98 \%$ pollution free; biodegradable; renewable; there is no carbon left when ethanol burns in cars; ethanol does not cause climate change; and all the by-products in the production of ethanol are edible and nontoxic, providing a very good source for animal feedstock.

Methanol has also been proposed as a fuel for internal combustion and other engines mainly in combination with gasoline. Historically, methanol was first produced from pyrolysis of wood. Presently, methanol is usually produced using methane as a raw material. Both methanol and ethanol burn at lower temperatures than gasoline, and both are less volatile, making engine starting in cold weather more difficult. Using methanol as a fuel in spark ignition engines can offer an increased thermal efficiency and increased power output due to its high octane rating (114) and high heat of vaporization. However, its low energy content of 19.7 $\mathrm{MJ} / \mathrm{kg}$ and stoichiometric air fuel ratio of 6.42:1 mean that fuel consumption will be higher than hydrocarbon fuels [6]. Ethanol $\left(\mathrm{CH}_{3} \mathrm{CH}_{2} \mathrm{OH}\right)$ is more reactive than hydrocarbon fuels, such as gasoline. Since it is an alcohol, its molecular structure shows a polar fraction due to the hydroxyl radical and a non polar fraction in its carbon chain. That explains why ethanol can be dissolved in both gasoline (non polar) and in water (polar). Due to its short carbon chain, the properties of ethanol polar fraction overcome the non polar properties. The formation of hydrogen bridges in ethanol molecule results in higher boiling temperature in comparison to that of gasoline. Ethanol is less toxic than methanol - another alcohol used as fuel. The simple structure of ethanol molecule makes it suitable for spark ignition internal combustion engines operation. The high octane number of ethanol allows for higher compression ratios in comparison to gasoline fuelled engines [7] .In Brazil, ethanol is produced from sugar-cane, a renewable energy source. Sugar cane molasses contains about $40 \%$ sucrose, which hydrolysis by an enzyme called invertase produces glucose or fructose. The enzyme is elaborated by brewer's yeast. Ethanol is formed by glucose $\left(\mathrm{C}_{6} \mathrm{H}_{12} \mathrm{O}_{6}\right)$ fermentation in the presence of another enzyme called zymase. This is shown in the equations below;

$$
\begin{aligned}
& \mathrm{C}_{12} \mathrm{H}_{22} \mathrm{O}_{11}+\mathrm{H}_{2} \mathrm{O} \rightarrow \mathrm{C}_{6} \mathrm{H}_{12} \mathrm{O}_{6}+(2-x) \mathrm{C}_{6} \mathrm{H}_{12} \mathrm{O}_{6} \quad 0 \leq x \leq 1 \ldots \ldots \ldots \text { (1) }
\end{aligned}
$$

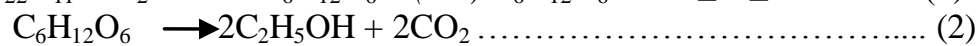


Given the foregoing, the objective of this study was therefore to investigate the performance characteristics of a 2000rpm single cylinder gasoline generator engine using ethanol:gasoline fuel mixing ratios.

\section{METHODOLOGY}

\subsection{Experimental Procedure}

\subsubsection{Biodiesel Synthesis}

Groundnut shells of samnut-38 specie was obtained from institute of agricultural research, Samaru Zaria and taken to the microbiology laboratory Ahmadu Bello University Zaria for synthesis. Groundnut shells are agricultural residues and a readily available source of lignocelluloses. This residue was washed with distilled water and then dried for three days at $60^{\circ} \mathrm{C}$ in a hot air memmert oven. This was done to reduce the moisture content and make them more susceptible to milling.

The substrate was milled with mortar and pistil, sieved to pass through a mesh sieve. $1500 \mathrm{~g}$ of the sample was weighed and then soaked in $1 \%(\mathrm{w} / \mathrm{v})$ sodium hydroxide solution (substrate + solution) for 2 hours at room temperature after which it was washed with distilled water and dilute HCL until the wash water was neutral on $\mathrm{PH}$ scale. It was then set in memmert oven (Model UE-500 DINII2880) overnight at $60^{\circ} \mathrm{C}$ to dry. The fermentation medium used for the ethanol production consisted of glucose $8 \%(\mathrm{w} / \mathrm{v})$ peptone $0.1 \%(\mathrm{w} / \mathrm{v})$, malt extract $0.1 \%(\mathrm{w} / \mathrm{v})$, yeast extract $0.2 \%(\mathrm{w} / \mathrm{v})$, ammonium sulphate $0.2 \%(\mathrm{w} / \mathrm{v})$ and ferrous sulphate, $0.001 \%(\mathrm{w} / \mathrm{v})$. $200 \mathrm{ml}$ medium culture was prepared and $300 \mathrm{ml}$ dispense was added into each $500 \mathrm{ml}$ erlenmeyer flask. The flasks were sterilized in an autoclave (Model Astell ASB 300) at $121^{\circ} \mathrm{C}$ for 15 minutes at $151 \mathrm{bs}$ pressure and inoculated with $15 \mathrm{ml}$ and $4 \mathrm{ml}$ containing growth innocula of S. cerevesiae and A. niger cells and 2 million spores respectively.

The flasks were incubated on orbital shaker (Model vineland NJ SH2-526) with an initial agitation rate of $300 \mathrm{rpm}$ at $30^{\circ} \mathrm{C}$ for seven days. The sample was withdrawn at interval of 24 hours for distillation.

\subsubsection{Fuel Properties Determination}

Fuel properties of tested blends were determined in accordance with American Standard for Testing Materials (ASTM) procedures for petroleum products.

Each fuel sample was evaluated to determine the density, API gravity, heat of combustion. The density of each tested sample was measured by hydrometer method (ASTM D287 Standard). The API gravity was calculated from density results. Heat of combustion was measured in record bomb calorimeter according to PARR 1266 standards, France (ASTM D240).

\subsubsection{Engine Performance Evaluation}

A load test was done with gasoline and its blends with ethanol as fuel on the Peters PIAW carburetted single cylinder four stroke SI engine with maximum speed of 2000rpm.

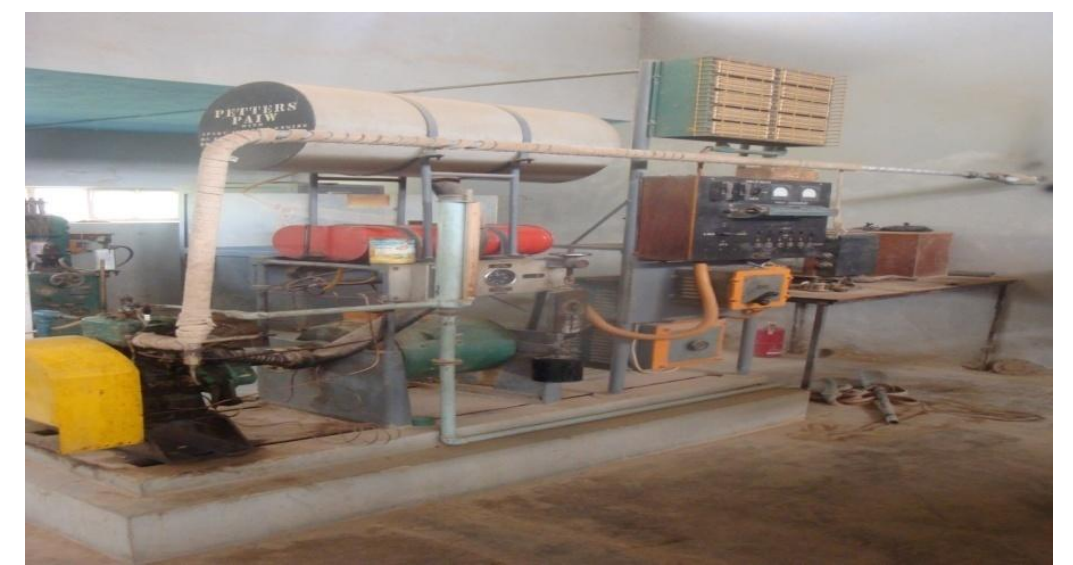

Figure 1: A pictorial view of the Peters PAIW S.I engine used in this study.

This was done to obtain a set of performance parameters. The performance parameters were calculated using the following equations:

\section{Brake Power}

$$
B P=\frac{W \times N \times 0.736}{C}
$$

Where; 
$\mathrm{BP}=$ Break Power $(\mathrm{KW})$

$\mathrm{W}=$ weight reading from scale in $\mathrm{kg}$

$\mathrm{N}=$ speed of the engine in $\mathrm{rpm}$

$\mathrm{C}=$ constant 1000

\section{Mass of fuel consumed}

Where;

$$
m f c=\frac{X C C \times 0.72 \times 3600}{1000 \times T}
$$

$\mathrm{mfc}=$ mass of fuel consumed

$\mathrm{XCC}=$ Burette reading in $\mathrm{mm}$

$0.72=$ density of gasoline in gram $/ \mathrm{mm}$

$\mathrm{T}=$ time taken in seconds

\section{Specific fuel consumption}

$$
\text { Specific fuel consumption }(s f c)=m f c / B P
$$

\section{Actual volume of air sucked into the cylinder}

$$
\text { actual air volume suck into cylinder }\left(V_{a}\right)=3600 \times C_{d} \times A \times \sqrt{2 g H}
$$
Where;

$$
H=\frac{h}{1000 x\left({ }^{\rho w} / \rho a\right)}
$$

$\mathrm{d}=20 \mathrm{~mm}$

$\mathrm{A}=$ Area of orifice $=\pi d^{2} / 4=3.14 \times 10^{-4}$

$\mathrm{h}=$ manometer reading in $\mathrm{mm}$

$\rho_{\mathrm{w}}=$ density of water $=1000 \mathrm{~kg} / \mathrm{m}^{3}$

$\rho_{\mathrm{a}}=$ density of air $=1.193 \mathrm{~kg} / \mathrm{m}^{3}$

$\mathrm{C}_{\mathrm{d}}=$ coefficient of discharge $=0.62$

$\mathrm{g}=$ acceleration due to gravity $=9.81 \mathrm{~m}^{2} / \mathrm{s}$

5. Swept volume

$$
V_{s}=\pi d_{m}^{2} / 4 \times L \times N / 2 \times 3 \times 60
$$

Where, $\mathrm{V}_{\mathrm{s}}=$ Swept Volume

$\mathrm{d}_{\mathrm{m}}=$ diameter of the bore $=0.0685 \mathrm{~m}$

$\mathrm{L}=$ length of the stroke $=0.072 \mathrm{~m}$

$\mathrm{N}=$ speed of the engine in rpm

\section{Volumetric efficiency}

$$
\text { Volumetric efficiency }\left(\eta_{v}\right)=V_{a} / V_{s} \times 100
$$

\section{RESULTS AND DISCUSSION}

The Calorific value, density and Specific gravity of Blends of gasoline and ethanol produced from Groundnut shell is presented in the table 1 below.

Table 1: Some Properties of Blends of gasoline and ethanol produced.

\begin{tabular}{|l|l|l|l|l|l|l|l|}
\hline S/No & $\begin{array}{l}\text { SAMPLE } \\
\text { ID }(\%)\end{array}$ & $\begin{array}{l}\text { GROSS } \\
\text { HEAT } \\
(\mathrm{MJ} / \mathrm{KG})\end{array}$ & $\begin{array}{l}\text { INITIAL } \\
\text { TEMPT., } \\
\left({ }^{0} \mathrm{C}\right)\end{array}$ & $\begin{array}{l}\text { FINAL } \\
\text { TEMPERATURE } \\
\left({ }^{0} \mathrm{C}\right)\end{array}$ & $\begin{array}{l}\text { SAMPLE } \\
\text { WEIGHT } \\
(\mathrm{g})\end{array}$ & $\begin{array}{l}\text { DENSITY } \\
\left(\mathrm{Kg} / \mathrm{m}^{3}\right)\end{array}$ & $\begin{array}{l}\text { SPECIFIC } \\
\text { GRAVITY }\end{array}$ \\
\hline 1 & $\mathrm{E}_{0}$ & 480.2900 & 23.7654 & 26.6705 & 0.0001 & 703.5 & 0.7035 \\
\hline 2 & $\mathrm{E}_{20}$ & 459.0304 & 24.1345 & 25.4115 & 0.0001 & 712.3 & 0.7144 \\
\hline 3 & $\mathrm{E}_{40}$ & 437.6332 & 23.9650 & 24.1783 & 0.0001 & 724.2 & 0.7343 \\
\hline 5 & $\mathrm{E}_{60}$ & 364.1156 & 24.9673 & 25.3214 & 0.0001 & 737.9 & 0.7453 \\
\hline
\end{tabular}

From the results obtained, it was observed that the gross heat of the blend was decreasing with increase in the percentage of ethanol added. On the other hand the density and specific gravity of the blend are increasing with increase in the percentage of ethanol added. This implies that the mass of the synthesized ethanol is higher that of pure gasoline which resulted in the increase of the blends' densities. 


\subsection{Engine Performance Analysis}

For the experiment, the electrical load from the dynamometer was varied and the resultant mechanical load was noted for each sample at various speeds. Tables 2, 3, and 4, given below are for the samples test conducted. Data were obtained based on the engine operating parameters and instrument readings.

Table 2: Specific Fuel Consumption (SFC) at different Engine Speed

\begin{tabular}{|c|c|c|c|c|c|}
\hline \multirow{2}{\text{Spamples}}{} & $\begin{array}{c}\mathrm{E}_{0} \\
(\mathrm{~kg} / \mathrm{Whr})\end{array}$ & $\begin{array}{c}\mathrm{E}_{20} \\
(\mathrm{~kg} / \mathrm{Whr} .)\end{array}$ & $\begin{array}{c}\mathrm{E}_{40} \\
(\mathrm{~kg} / \mathrm{Whr} .)\end{array}$ & $\begin{array}{c}\mathrm{E}_{60} \\
(\mathrm{~kg} / \mathrm{Whr})\end{array}$ & $\begin{array}{c}\mathrm{E}_{80} \\
(\mathrm{~kg} / \mathrm{Whr} .)\end{array}$ \\
\hline 1000 & 0.27 & 0.31 & 0.32 & 0.32 & 0.34 \\
\hline 1200 & 0.31 & 0.33 & 0.36 & 0.32 & 0.34 \\
\hline 1400 & 0.32 & 0.40 & 0.37 & 0.36 & 0.33 \\
\hline 1600 & 0.41 & 0.39 & 0.36 & 0.37 & 0.33 \\
\hline 1800 & 0.42 & 0.36 & 0.35 & 0.34 & 0.32 \\
\hline
\end{tabular}

Table 3: Engine Power at different Engine Speed

\begin{tabular}{|c|c|c|r|r|r|}
\hline \multirow{2}{\text{Samples}}{} & $\begin{array}{c}\mathrm{E}_{0} \\
(\mathrm{KW})\end{array}$ & $\begin{array}{c}\mathrm{E}_{20} \\
(\mathrm{KW})\end{array}$ & $\begin{array}{c}\mathrm{E}_{40} \\
(\mathrm{KW})\end{array}$ & $\begin{array}{c}\mathrm{E}_{60} \\
(\mathrm{KW})\end{array}$ & \multicolumn{1}{c|}{$\begin{array}{c}\mathrm{E}_{80} \\
(\mathrm{KW})\end{array}$} \\
\hline 1000 & 1.05 & 1.45 & 1.55 & 1.50 & 1.35 \\
\hline 1200 & 1.25 & 1.75 & 1.70 & 1.72 & 1.71 \\
\hline 1400 & 1.85 & 1.95 & 2.30 & 2.15 & 2.10 \\
\hline 1600 & 1.70 & 2.25 & 2.70 & 2.30 & 2.35 \\
\hline 1800 & 2.05 & 2.55 & 2.70 & 2.60 & 2.60 \\
\hline
\end{tabular}

Table 4: Volumetric Efficiency at different Engine Speed

\begin{tabular}{|c|c|c|c|r|r|}
\hline Speed rpm & $\begin{array}{c}\mathrm{E}_{0} \\
(\%)\end{array}$ & $\begin{array}{c}\mathrm{E}_{20} \\
(\%)\end{array}$ & $\begin{array}{c}\mathrm{E}_{40} \\
(\%)\end{array}$ & $\begin{array}{c}\mathrm{E}_{60} \\
(\%)\end{array}$ & $\begin{array}{l}\mathrm{E}_{80} \\
(\%)\end{array}$ \\
\hline 1000 & 0.44 & 0.47 & 0.51 & 0.50 & 0.49 \\
\hline 1200 & 0.46 & 0.52 & 0.53 & 0.52 & 0.51 \\
\hline 1400 & 0.52 & 0.58 & 0.62 & 0.59 & 0.57 \\
\hline 1600 & 0.53 & 0.65 & 0.76 & 0.71 & 0.68 \\
\hline 1800 & 0.62 & 0.65 & 0.89 & 0.81 & 0.76 \\
\hline
\end{tabular}

Figure 2 shows the effect of the ethanol fuel blending on the specific fuel consumption (SFC). The specific fuel consumption is slightly increased as the volume percentage of ethanol fuel increases in the mixture. This is due to the lower heating value of ethanol compared with gasoline (Table 2). From the graph, it was observed that the specific fuel consumption increases as the engine speed increases for control, but rises to a peak and fall at higher engine speed for the blends. Maximum specific fuel consumption of $0.4 \mathrm{~kg} / \mathrm{Whr}$, $0.37 \mathrm{~kg} / \mathrm{Whr}$ and $0.37 \mathrm{~kg} / \mathrm{Whr}$ was obtained for $\mathrm{E}_{20}, \mathrm{E}_{40}$ and $\mathrm{E}_{60}$ at an engine speed of about 1400rpm for $\mathrm{E}_{20}$ and 1600rpm for samples $\mathrm{E}_{40}$ and $\mathrm{E}_{60}$ respectively. For sample $\mathrm{E}_{80}$, the specific fuel consumption with respect to speed is almost linear; therefore, approximately constant with only a slight variation for increasing speed. 


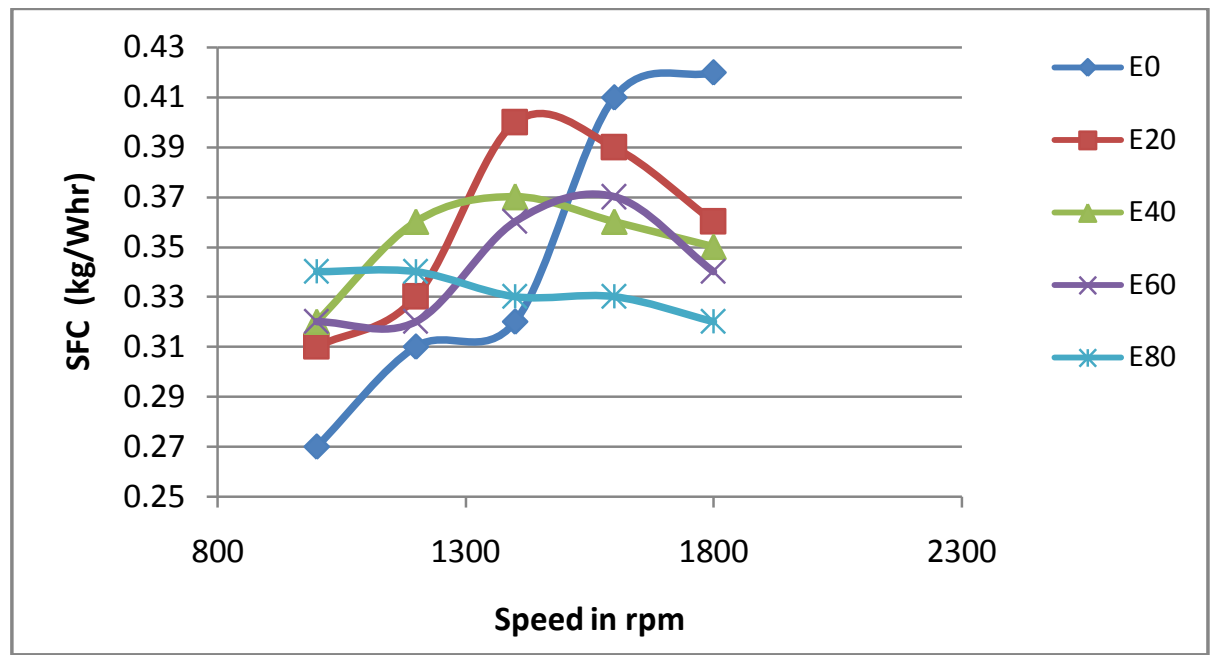

Figure 2: Effect of ethanol blends on the specific fuel consumption

Figure 3 shows the effect of the ethanol fuel blending on the brake power. As the ethanol content in the blend fuel increases, power also dramatically increases. This can be associated with higher heat of evaporation of ethanol compare to that of gasoline. High heat of evaporation can provide cooling for fuel-air charge, hence its density increases. Thus higher power output is obtained from the blends. However, power increase starts to decrease when ethanol content is more than $40 \%$. This is due to the lower heating value of ethanol compared with gasoline (Table 3).

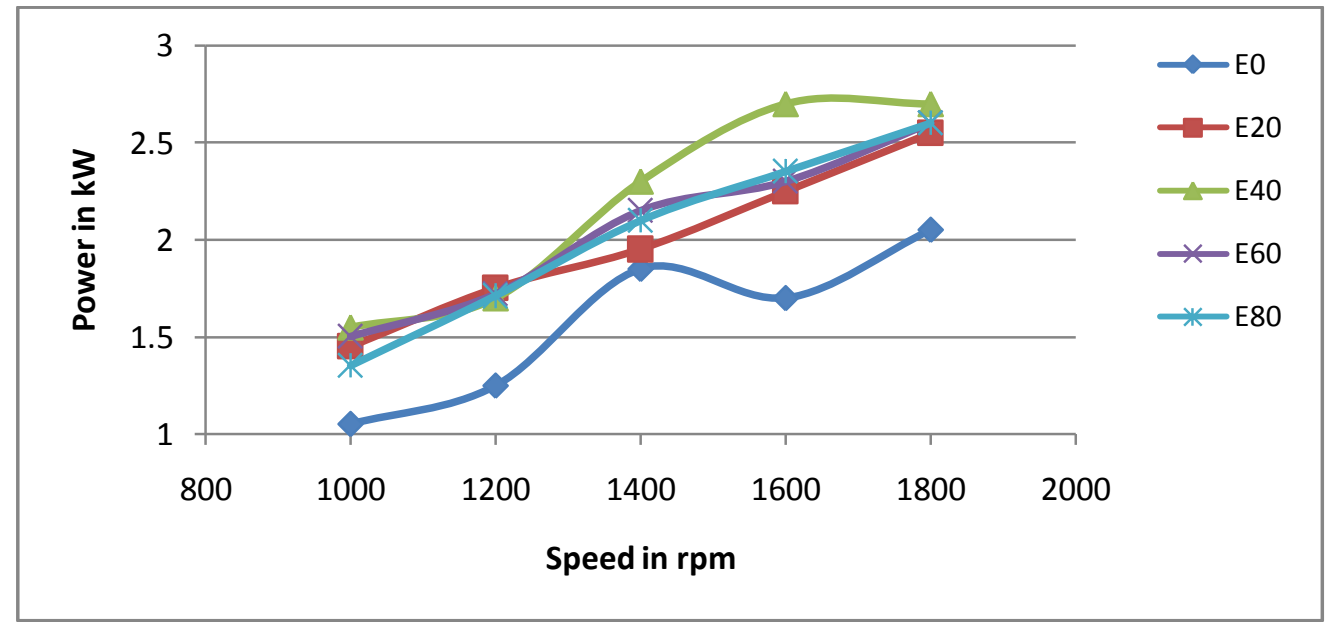

Figure 3: Effect of ethanol-gasoline blends on the engine power

Figure 4 shows the effect of the ethanol fuel blending on the volumetric efficiency. The volumetric efficiency increases as the volume percentage of ethanol fuel increases in the mixture. The heat of evaporation of ethanol is about 2.75 times higher than that of gasoline (Table 4), and this reduces the temperature of the intake manifold, and increases the volumetric efficiency. However, the volumetric efficiency starts to decrease when ethanol content is more than $40 \%$. 


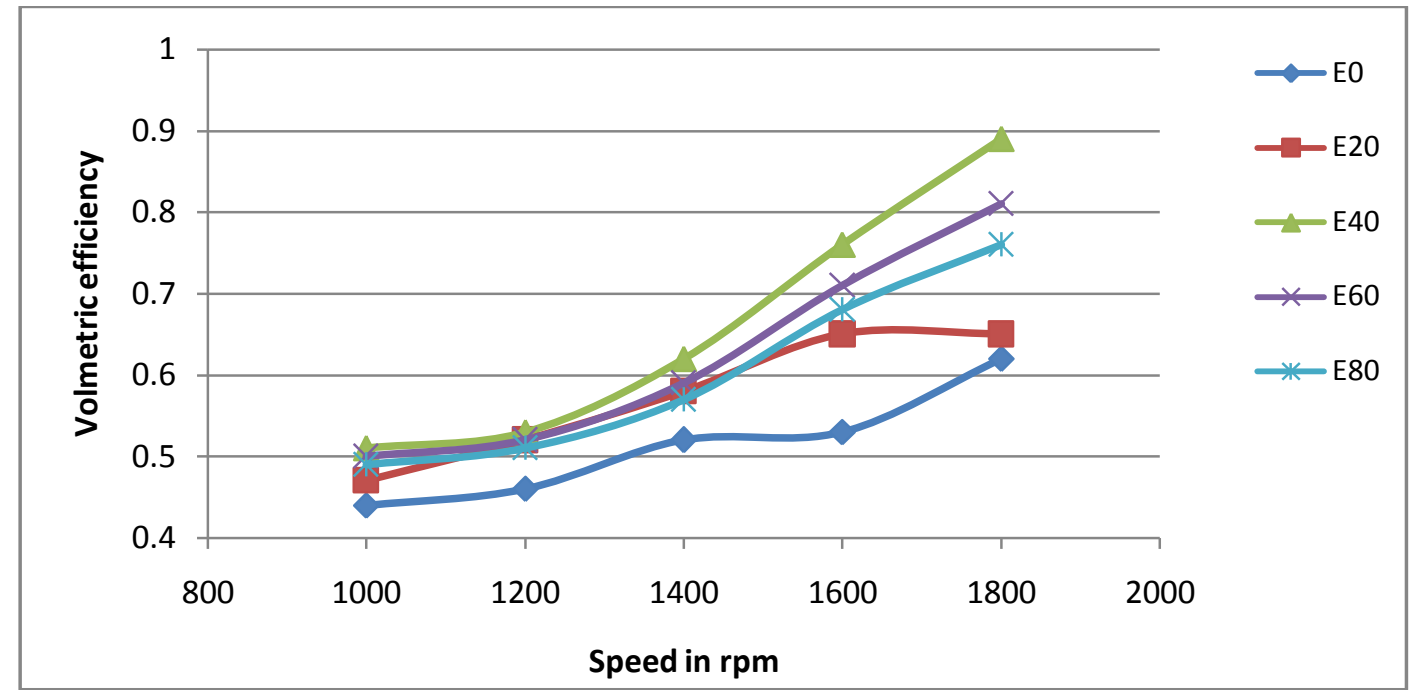

Figure 4: Effect of ethanol-gasoline blend on the volumetric efficiency

\section{CONCLUSION}

Experiments have been conducted on a single cylinder petrol engine with different percentage of ethanol as additive to gasoline in respect to their performance indicating parameters. It is concluded that, increase in the engine speed causes increase in the rate of fuel consumption for control sample, while it decreases at higher speed for the blends. Furthermore, increase in percentage composition of ethanol increases the engine power and volumetric efficiency while the highest engine power of $2.70 \mathrm{KW}$ and volumetric efficiency of 0.76 were obtained from blend $\mathrm{E}_{40}$. Thus ethanol may be used as an additive for gasoline engines.

\section{REFERENCES}

[1] T. Coppin, O. Grondin, N. Maamri, and L. Rambault, "Fuel estimation and air-to-fuel ratio control for flex fuel spark-ignition engines," 2010 IEEE International Conference on Control Applications, 2010.

[2] K. Nakata, S. Utsumi, A. Ota, K. Kawatake, T. Kawai, andT. Tsunooka, "The effect of ethanol fuel on a spark ignition engine,"SAE 2006-01-3380, 2006.

[3] P. Caton, L. Hamilton, and J. Cowart, "An experimental and modeling investigation into the comparative knock and performance characteristics of e85, gasohol [e10] and regular unleaded gasoline [87(r+m)/2],"SAE 2007-01-0473, 2007.

[4] Licht, F.O. World Fuel Ethanol Production. Renewable Fuels Association 2009. www.ethanolrfa.org/industry/statistics/\#E.

[5] Blume, D, Alcohol Can Be a Gas; Fueling an Ethanol Revolution for the 21st Century, International Institute for Ecological Agriculture,2007. California, pp. 344.

[6] M.V. Mallikarjun and V.R Mamilla, Experimental Study of Exhaust Emissions \&Performance Analysis of Multi Cylinder S.I.Engine when Methanol Used as an Additive, International Journal of Electronic Engineering Research, 1(3),2009 pp. 201-212

[7] M. Al-Hassan; Effect of ethanol- unleaded gasoline blends on engine performance and exhaust emission. Energy Conversion and Management; 44(9): 2003 pp.1547-1561 